\title{
CLARIFICATION OF TWO TAXON NAMES IN PHRAGMIPEDIUM (ORCHIDACEAE, CYPRIPEDIOIDEAE)
}

\author{
Edgar Mó ${ }^{1,2,5}$, Eduardo A. Pérez-García ${ }^{3} \&$ William Cetzal-IX ${ }^{4}$ \\ ${ }^{1}$ Orquideario Agronomía-CUNOR-USAC, Centro Universitario del Norte, \\ Universidad de San Carlos de Guatemala, Cobán, Alta Verapaz, Guatemala \\ ${ }^{2}$ Orquigonia, Centro de Rescate y Conservación de Orquídeas, Cobán, Alta Verapaz, Guatemala \\ ${ }^{3}$ Departamento de Ecología y Recursos Naturales, Facultad de Ciencias, Universidad Nacional Autónoma \\ de México, Ciudad Universitaria, Del. Coyoacán, 04510, México, D.F., México \\ ${ }^{4}$ Instituto Tecnológico de Chiná, Calle 11, Colonia Centro Chiná 24050, Campeche, México \\ ${ }^{5}$ Author for correspondence: alfredomo2@hotmail.com
}

\begin{abstract}
The names of two subspecies of Phragmipedium humboldtii from Guatemala, P. humboldtii subsp. monstruosum and P. humboldtii subsp. triandrum (Orchidaceae, Cypripedioideae) were wrongly cited when proposed in Die Orchidee 66(3), 2015. The new status of these subspecies was based on an incorrect authorship of $P$. humboldtii, which instead of (Warsz. ex Rchb.f.) J.T. Atwood \& Dressler, should be (Warsz.) J.T. Atwood $\&$ Dressler. The formal names of the subspecies are clarified here.
\end{abstract}

KeY wORDS: Guatemala, invalid names, Lady slippers, nomenclature, subspecies

The genus Phragmipedium Rolfe includes 22 species, four subspecies and three natural hybrids, ranging from Mexico to South America (Gruss 2003; Pérez-García \& Mó Mó 2015). Most species occur in South America and only a few in Mexico and Central America. In Guatemala, only four subspecies of $P$. humboldtii (Warsz.) J.T.Atwood \& Dressler have been formally recorded: $P$. humboldtii subsp. humboldtii, $P$. humboldtii subsp. exstaminodium (Castaño, Hágsater \& E.Aguirre) J.T.Atwood \& Dressler ex J.M.H.Shaw, P. humboldtii subsp. triandrum (Archila) Mó \& Pérez-García and P. humboldtii subsp. monstruosum (Archila) Mó \& Pérez-García (Pérez-García \& Mó Mó 2015). However, the new status of these last two subspecies was wrongly cited by Pérez-García and Mó Mó (2015: 222), because previously Pupulin and Dressler (2011) indicated that the correct name for this species is P. humboldtii (Warsz.) J.T.Atwood \& Dressler instead of $P$. humboldtii (Warsz. ex Rchb.f.) J.T.Atwood \& Dressler. Hence, P. humboldtii (Warsz.) J.T.Atwood \& Dressler subsp. triandrum (Archila) Mó $\&$ Pérez-García and P. humboldtii (Warsz.) J.T.Atwood
\& Dressler subsp. monstruosum (Archila) Mó \& PérezGarcía is how these subspecies have to be correctly named.

ACKNOWLEDGEMENTS. We thank Gustavo Romero-González (AMES) and Franco Pupulin (JBL) and two anonymous reviewers by the comments and recommendations to improve this article.

\section{Literature Cited}

Archila, M. (1999). Dos nuevas entidades del género Phragmipedium Rolfe para Guatemala, Phragmipedium monstruosum Archila y Phragmipedium triandum Archila. Revista Guatemalensis, 2: 3-9.

Gruss, O. (2003). A checklist of the genus Phragmipedium. Orchid Digest, 67: 213-241.

Pérez-García, E.A. \& Mó Mó, E.A. (2015). Die Cypripediodeae von Mesoamerika Teil 2b Phragmipedium. Die Orchidee, 66(3): 216-225.

Pupulin, F. \& Dressler, R.L. (2011). A nomenclatural note on Cypripedium humboldtii (Orchidaceae: Cypripedioideae). Harvard Papers in Botany, 16(1): 157-159. 
